\title{
Boron determination in a multi element national water monitoring program: the absence of legal limits
}

\author{
Eleni Loizou • Popi Nicolaidou Kanari • \\ Georgia Kyriacou $\cdot$ Maria Aletrari
}

Received: 14 June 2010/ Accepted: 18 June 2010/Published online: 13 July 2010

(c) The Author(s) 2010. This article is published with open access at Springerlink.com

\begin{abstract}
Directive 98/83/EC concerning the drinking water quality and Directive 80/777/EC for Natural Mineral Water demand strict control and monitoring for the presence of metals. The State General Laboratory as the official control laboratory (Accredited by ISO 17025:2005) implements a national monitoring program in order to ensure that the drinking and natural mineral water quality satisfy the requirements of the respective Directives. The National Monitoring program covers mainly metals such as $\mathrm{Pb}, \mathrm{Cd}, \mathrm{Cr}, \mathrm{Ni}$, $\mathrm{As}, \mathrm{Se}, \mathrm{Sb}, \mathrm{Hg}, \mathrm{Mn}, \mathrm{Cu}, \mathrm{Fe}, \mathrm{Al}$ and $\mathrm{B}$ in water supplied for human consumption either by distribution networks, vending machines, mobile water containers, ground water intended for human consumption as well as bottled water. The determination of metals in water by Inductively Coupled Plasma-Mass Spectroscopy (ICPMS) is a technique that successfully meets the requirements of the above Directives as it is a very powerful tool for the measurement of metals at very low concentrations with high accuracy and precision. The results obtained indicate that metal concentrations in drinking and bottled water examined were by far, below the acceptable legal limits and even below the relevant detection limits. However, in samples of bottled natural mineral water, high boron concentration were determined and risk assessment was performed due to the absence of relevant legal limits. The present paper demonstrates the steps undertaken by the General Water Analysis Laboratory of the SGL
\end{abstract}

\footnotetext{
Dr. E. Loizou · Dr. P. N. Kanari ( $₫)$ · G. Kyriacou · M. Aletrari

State General Laboratory, Ministry of Health, General Water Analysis Lab, 44 Kimonos Str., 1451 Nicosia, Cyprus

e-mail: pkanari@sgl.moh.gov.cy
}

for the validated method used by ICP-MS in the determination of trace metals including boron in drinking and bottled water.

Keywords Boron - Natural mineral water . Directive 80/777/EC · ICP / MS · Validation

\section{Introduction}

Boron is an ubiquitous element in rocks, soil and water. Most of the earth's soils have less than $10 \mathrm{ppm}$ boron. Freshwaters normally range from less 0.1-1.5 ppm, with higher concentration in regions of high boron soil levels (WHO 1998). The greatest exposure to boron for most populations comes from food. Food rich in boron includes fruits, leafy vegetables, mushrooms, nuts, legumes, wine cider and beer. The daily intake of boron by humans can vary widely depending on the proportion of various food groups in the diet. Vegetarians are identified as a potential high intake group (EFSA 2004).

Water and particularly mineral water can be an important source of boron intake. The natural borate content of ground water and surface water is usually small. Natural occurring boron is present in ground water primarily as a result of leaching from rocks and soils containing borates and borosilicates. Concentration of boron in ground water throughout the world range widely from $<0.3$ to $>100 \mathrm{ppm}$. In general, the amount of boron in fresh water depends on such factors as the geochemical nature of the drainage area, proximity to marine costal regions and imputes from industrial and municipal effluents. 
According to WHO (1998) and EFSA (2004), shortand long-term of oral exposure to boron affects mainly the male reproductive system, which is a consistent target of toxicity. Furthermore, it penetrates the placenta with an embryo negative result. Until 2004, data on adverse effects of boron in humans where not adequate for establishing a tolerable upper intake level (WHO 1998). The WHO guideline value for boron in drinking water is $0.5 \mathrm{ppm}$, which is attributed to $10 \%$ contribution from total exposure in boron. The relevant legal limit of Directive 98/83/EE is $1 \mathrm{ppm}$ and the Codex Standard limit for natural mineral water is 5 ppm (1981).

EFSA (2005) defines that tolerable daily intake (TDI) for adults is $10 \mathrm{mg}$ boron / $\mathrm{kg}$ body weight/day. With an allocation of $10 \%$ of the TDI to drinking water (according to WHO 1998), the boron concentration must not exceed the $1 \mathrm{mg} / \mathrm{kg}$ body weight/day.

The measurement of metals and boron in drinking water at the laboratory was performed by ICP-MS. The present study demonstrates the steps undertaken for the validation of the ICP-MS method and the risk assessment carried out for boron determined in natural mineral water samples.

\section{Materials and methods}

\subsection{Sampling and preservation}

Water samples were collected in 1,000 ml PET bottles and $3 \mathrm{ml}$ of $(1+1)$ nitric acid solution was added to the samples for preservation. They were further stored at $4{ }^{\circ} \mathrm{C}$ and analyzed within a month.

\subsection{Reagents and quality control}

Suitable analytical reagents, instrument optimization / tuning solution, standards of ultra pure quality were used. Quality control system during routine analysis includes certified reference materials (NIST, LGC, NWRI, etc.), spikes, blanks, duplicates known addition samples and calibration verification standards. Moreover, the laboratory participated in appropriate proficiency testing schemes (AQUACHECK, etc.) in order to ensure the reliability and comparability of the results.

\subsection{Equipment}

Inductively Coupled Plasma-Mass Spectroscopy (ICPMS): Agilent technologies 7500 ce, equipped with Micromist glass concentric nebulizer and Agilent CETAC ASX-510 auto sampler (Agilent Technologies).

\subsection{Analytical procedure}

The applied method which is accredited for the determination of trace metals and boron in drinking and bottled water was based on the Standard Method APHA 3125B. The specific ICP / MS measurement parameters are shown in Table 1.

\subsection{Method validation}

The method validation included the following steps: trueness control, precision (repeatability and withinlaboratory reproducibility), experiments, check of the linearity of the standard calibration curves, determination of the detection / quantitation limits and method uncertainty study. The results were satisfactory and within the accepted validation requirements. Representative calculated results of the above experiments are presented in Table 2.

\subsection{Uncertainty estimation}

The contribution of different sources of the method uncertainty was studied in the determination of the above metals at various levels. Below, an example for

Table 1 Agilent ICP / MS measuring parameters

\begin{tabular}{|c|c|c|c|}
\hline Plasma parameters & Ion lenses & ORS & Quadrupole \\
\hline RF Power (1,500-1,550 W) & Extract $11-5 \mathrm{~V}$ & Cell entrance $022 \mathrm{~V}$ & QP Bias $-3 \mathrm{~V}$ \\
\hline RF matching & Extract 2 150-(-120 V) & Cell exit $-22 \mathrm{~V}$ & \\
\hline Sample depth $8 \mathrm{~mm}$ & Omega bias $-20 \mathrm{~V}$ & Octopole RF & \\
\hline Torch-H & Omega lens $2.5 \mathrm{~V}$ & Octopole Bias $-6 \mathrm{~V}$ & \\
\hline Torch-V & $\mathrm{QP}$ focus $3 \mathrm{~V}$ & & \\
\hline \multicolumn{4}{|l|}{ Carrier gas $1.05 \mathrm{I} / \mathrm{ml}$} \\
\hline \multicolumn{4}{|l|}{ Makeup gas $0-0.3 \mathrm{l} / \mathrm{min}$} \\
\hline \multicolumn{4}{|l|}{ Peripump 0.1 rps } \\
\hline $\mathrm{S} / \mathrm{C}$ Temp $2{ }^{\circ} \mathrm{C}$ & & & \\
\hline
\end{tabular}




\section{$\%$ Contribution of various sources of uncertainty}

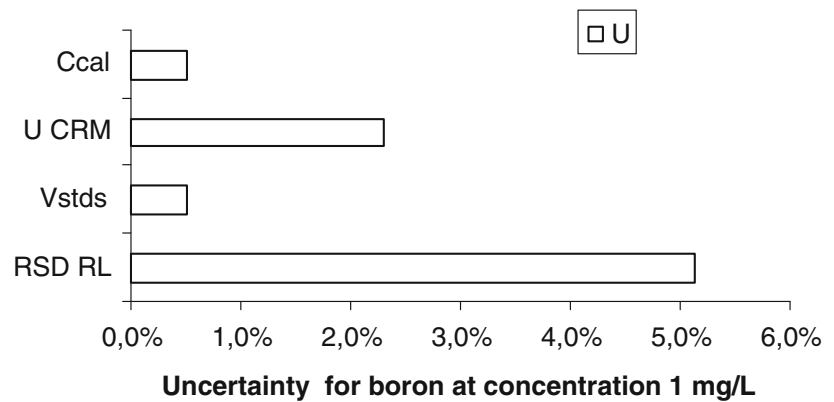

Fig. 1 Sources of method uncertainty

the procedure followed for boron uncertainty evaluation is described. The contribution of each of the following sources was studied: (a) The relative standard uncertainty of the method, determined from interlaboratory reproducibility tests $\left(\mathrm{RSD}_{\mathrm{RL}}\right)$, (b) The uncertainty from the reference calibration curve: (Uc/c), (c) The uncertainty due to the method and laboratory bias. This was determined from sixfold recovery tests: $\left(\mathrm{U}_{\text {bias }} / \mathrm{R}\right)$, (d) The uncertainty from volumetric flasks/pipettes used for the preparation of standards solutions: (Uv/V).

The total combined uncertainty of the method was calculated using the following formula:

$\mathrm{Uc} / \mathrm{C}=\sqrt{\left(\mathrm{RSD}_{\mathrm{RL}}\right)^{2}}+(\mathrm{Uc} / \mathrm{c})^{2}+\left(\mathrm{U}_{\text {bias }} / \mathrm{R}\right)^{2}+(\mathrm{Uv} / \mathrm{V})^{2}$

Figure 1 shows the contribution of each uncertainty source to the method uncertainty for boron determination.

\section{Results and discussion}

The results obtained within the implementation of the national monitoring program, indicated that metal concentrations in potable and bottled water examined, were by far below the acceptable legal limits and even below the relevant detection limits. An exception was the case of high boron levels in samples of imported carbonated natural mineral water (NMW) of the same brand. Due to the absence of upper accepted limits for boron, legal ambiguities were raised.

The Directive 2003/40/EC on natural mineral waters does not define any limits for boron, despite the fact that the deadline for setting such a limit was January 2006. The Codex Standard for Natural Mineral Waters defines the health-related limit for boron as $5 \mathrm{mg} / \mathrm{L}$. Furthermore, Directive 98/83/EC concerning drinking water quality, defines an upper accepted limit of $1 \mathrm{mg} / \mathrm{L}$ for boron, however, excludes NMW. In addition, WHO provisional guideline value for boron (1998) in drinking water is $0.5 \mathrm{mg} / \mathrm{L}$. Risk Assessment was performed, based on WHO recommendations (1998) and EFSA opinions (2005) which showed that water samples were considered as unsafe for human consumption. As a result, the import of the above samples was denied and the case was notified to rapid alert system for food and feed (RASFF).

The results of the samples of imported carbonated natural mineral water for boron content are shown in Table 3.

\section{Boron risk assessment}

In Table 3 is shown: (a) the level found in samples of different batches from spring number 59 was approx. 13 times greater than WHO provisional guideline value (WHO 1998) for drinking water (0.5 mg/L), (b) 7 times the relevant legal limit of Directive 98/83/EE $(1 \mathrm{mg} / \mathrm{L})$, and (c) higher than the Codex Standard (1981) limit for NMW (5 mg/L). EFSA defines that boron TDI for adults is $10 \mathrm{mg} / \mathrm{kg}$ body weight/day
Table 2 Performance characteristics of metals determination by ICP / MS

\begin{tabular}{lclllc}
\hline Metal & Mass & LOQ $(\mu \mathrm{g} / \mathrm{L})$ & Spiking level $(\mu \mathrm{g} / \mathrm{L})$ & Recovery $(\%)$ & Precision (\%RSDr) \\
\hline $\mathrm{B}$ & 11 & 50 & 100 & 94.7 & 1.51 \\
$\mathrm{~Pb}$ & 208 & 1 & 5 & 92.4 & 1.0 \\
$\mathrm{Cr}$ & 53 & 1 & 10 & 100 & 1.4 \\
$\mathrm{Ni}$ & 60 & 1 & 10 & 98.7 & 1.9 \\
$\mathrm{Cd}$ & 111 & 0.5 & 1 & 96.7 & 5.4 \\
$\mathrm{As}$ & 75 & 1 & 10 & 100.6 & 0.8 \\
$\mathrm{Mn}$ & 55 & 10 & 10 & 91.7 & 2.5 \\
$\mathrm{Cu}$ & 63 & 1 & 10 & 108 & 10.8 \\
$\mathrm{Sb}$ & 121 & 1 & 1 & 113.3 & 3.2 \\
$\mathrm{Se}$ & 82 & 2 & 20 & 91.1 & 1.3 \\
\hline
\end{tabular}


Table 3 Results of the carbonated natural mineral water

\begin{tabular}{|c|c|c|c|c|}
\hline Spring no. & $\begin{array}{l}\text { Date of sample } \\
\text { received }\end{array}$ & Deviated parameter & $\begin{array}{l}\text { Results evaluation/risk assessment } \\
\text { by SGL }\end{array}$ & Recommendations and risk management \\
\hline 59 & $8 / 7 / 08$ & $\begin{array}{l}\mathrm{Cr}=67.2 \mu \mathrm{g} / \mathrm{L}^{\mathrm{a}} \\
\mathrm{B}=6.7 \mathrm{mg} / \mathrm{L}^{\mathrm{b}}\end{array}$ & $\begin{array}{l}\mathrm{Cr} \text { conc. exceeds the legal limit } \\
\mathrm{B} \text { conc. exceeds the available } \\
\text { accepted limits }^{\mathrm{b}}\end{array}$ & Sample rejection \\
\hline 59 & $8 / 10 / 08$ & $\mathrm{~B}=6.6 \mathrm{mg} / \mathrm{L}$ & $\begin{array}{l}\text { B conc. exceeds the available } \\
\text { accepted limits }^{b}\end{array}$ & Sample rejection \\
\hline 59 & $12 / 12 / 08$ & $\mathrm{~B}=6.9 \mathrm{mg} / \mathrm{L}$ & $\begin{array}{l}\text { B conc. exceeds the available } \\
\text { accepted limits }^{\mathrm{b}}\end{array}$ & Sample rejection \\
\hline 125 & $21 / 8 / 09$ & $\mathrm{~B}=3.5 \mathrm{mg} / \mathrm{L}$ & $\begin{array}{l}\text { B conc. exceeds the accepted limits } \\
\text { of Directive } 98 / 83 / \text { EE and WHO } \\
\text { provisional guideline value }\end{array}$ & $\begin{array}{l}\text { Recommendation for the following } \\
\text { labeling: consumption is not permitted } \\
\text { by children and pregnant and lactating } \\
\text { women }\end{array}$ \\
\hline 125 & $6 / 10 / 09$ & $\mathrm{~B}=4.4 \mathrm{mg} / \mathrm{L}$ & $\begin{array}{l}\text { B conc. exceeds the accepted limits } \\
\text { of Directive } 98 / 83 / \text { EE and WHO } \\
\text { provisional guideline value }\end{array}$ & $\begin{array}{l}\text { Recommendation for the following } \\
\text { labeling: consumption is not permitted } \\
\text { by children and pregnant and lactating } \\
\text { women }\end{array}$ \\
\hline 125 & $17 / 12 / 09$ & $\mathrm{~B}=4.3 \mathrm{mg} / \mathrm{L}$ & $\begin{array}{l}\text { B conc. exceeds the accepted limits } \\
\text { of Directive } 98 / 83 / \text { EE and WHO } \\
\text { provisional guideline value }\end{array}$ & $\begin{array}{l}\text { Recommendation for the following } \\
\text { labeling: consumption is not permitted } \\
\text { by children and pregnant and lactating } \\
\text { women }\end{array}$ \\
\hline 125 & $19 / 1 / 10$ & $\mathrm{~B}=4.4 \mathrm{mg} / \mathrm{L}$ & $\begin{array}{l}\text { B conc. exceeds the accepted limits } \\
\text { of Directive } 98 / 83 / \mathrm{EE} \text { and } \mathrm{WHO} \\
\text { provisional guideline value }\end{array}$ & $\begin{array}{l}\text { Recommendation for the following } \\
\text { labeling : consumption is not permittec } \\
\text { by children and pregnant women }\end{array}$ \\
\hline
\end{tabular}

Boron limit set in Codex Standard for Natural Mineral Waters is $5 \mathrm{mg} / \mathrm{L}$

Drinking Water Directive 98/83/EE parametric value for boron is $1 \mathrm{mg} / \mathrm{L}$

WHO provisional guideline value (for drinking water) for boron is $0.5 \mathrm{mg} / \mathrm{L}$

a Legal limit for $\mathrm{Cr}$ is $50 \mu \mathrm{g} / \mathrm{L}$ (Directives 80/777/EEC and 2003/40/EC)

b There is no legal limit for B yet (Directives $80 / 777 /$ EEC and 2003/40/EC)

(EFSA 2005). A $10 \%$ of the TDI is attributed to drinking water (according to WHO 1998), so the boron concentration must not exceed the $1 \mathrm{mg} / \mathrm{kg}$ body weight/ day.

Based on the above and according to article 10(a) of NMW Directive 80/777/EEC and article14 of Regulation EC No178/2002 the specific NMW was unsafe and considered to be injurious to health.

\section{Conclusion}

In order to satisfy both the legal aspect of the drinking water Directive 98/83/EU and Natural Mineral Water Directive 80/777/EC as well as the early response to any metal contamination, the State General Laboratory developed a validated method using ICP-MS.

According to Article 4 of the Drinking Water Directive 98/83/EC, the water intended for human consumption shall be wholesome and clean, which means that it must be free from any substances that in numbers or concentrations constitute a potential danger to human health. In the absence of legal limits for boron, it is obvious that Food Authorities look for a legal stronghold to take actions and carry out risk management especially when natural mineral waters are imported from an EU country. Furthermore, if action is taken with no legal bindings it could be considered as a barrier to free movement of goods within EU. Having in mind all the above complexities, but at the same time trying to protect Public Health, the Cyprus Risk Assessment/Risk Management Team recommended the following guidelines for natural Mineral Waters: (a) When concentration is equal or more than $5 \mathrm{mg}$ of boron per 1 liter recommended: batches of NMW will not be allowed to be imported, and (b) when concentration is between 1.5 and $5 \mathrm{mg}$ of boron per liter, appropriate labeling is used "consumption is not permitted by children and pregnant and lactating women”.

Having in mind all the above, despite the absence of maximum legal limits for substances that could pose a health risk to consumers, a national risk assessment should be carried out taking into account the measured level of these substances, national 
consumption figures for the general population and vulnerable groups, e. g. children, pregnant or lactating women. In the absence of legal limits, Risk Assessment can be based on WHO recommendations and EFSA opinions or other scientific opinions to minimize legal ambiguities and ensure as far as possible the protection of public health.

Acknowledgments We would like to thank Dr. E. Kakouri, Dr. P. Ziegler and Dr. S. Michaelidou for their contribution in boron risk assessment for natural mineral water.

Open Access This article is distributed under the terms of the Creative Commons Attribution Noncommercial License which permits any noncommercial use, distribution, and reproduction in any medium, provided the original author(s) and source are credited.

\section{References}

Agilent 7500 ICP-MS Chemstation (G1834B) Operators Manual (Agilent Technologies)

Codex Standard for Natural Mineral Waters. CODEX STAN 108-1981, Rev.1-199.7
Commission Directive 2003/40/EC of 16 May 2003, establishing the list, concentration limits and labeling requirements for the constituents of natural mineral waters and the conditions for using ozone-enriched air for the treatment of natural mineral waters and spring waters

Council Directive 80/777/EC of 15 July 1980 on the approximation of the laws of the Member States relating to the exploitation and marketing of natural mineral waters

Council Directive 98/83/EC of 3 November 1998 on the quality of water intended for human consumption

Eaton DA, Clesceri SL, Greenberg EA (2005) Method 3125B, inductively coupled plasma/mass spectrometry (ICP/MS) method. In: Clesceri SL, Greenberg EA (eds) Standard methods for the examination of water and wastewater, 21st edn. American Public Health Association, New York, pp 3-45

EFSA (2004) Scientific opinion on dietetic products, nutrition and allergies on a request from the commission related to the tolerable upper intake level of boron (Sodium Borate and Boric Acid) (Question number: EFSA-Q-2003-018). EFSA J 80:1-22

EFSA (2005) Scientific opinion related to concentration limits for boron and fluoride in natural mineral waters (Question number: EFSA-Q-2003-021). EFSA J 237:1-8

WHO (1998) Guidelines for drinking-water quality, 2nd edn. Addendum to vol 2. Health criteria and other supporting information. Boron in Drinking water. World Health Organization, Geneva 